\title{
Eläinten elektroninen merkintä elintarvikeketjussa
}

\author{
Hannu Haapala ${ }^{1)}$, Jukka Havento ${ }^{1)}$, Reima Kangasniemi ${ }^{2)}$ ja Mika Peltonen ${ }^{3)}$ \\ ${ }^{1)}$ MTT Maatalousteknologian tutkimus (Vakola) \\ Vakolantie 55, 03400 Vihti \\ ${ }^{2)}$ MTT Kotieläintutkimus \\ 31600 Jokioinen \\ ${ }^{3)}$ Työtehoseura Ry, Maatalousosasto \\ PL 1305201 Rajamäki
}

\section{Johdanto}

MTT:n Maatalousteknologian tutkimus (Vakola) ja Kotieläintuotannon tutkimus tutkivat EU:n Joint Research Centren (JRC, Ispra, Italia) ja MMM:n rahoittamassa hankkeessa eläinten elektronisen merkinnän toimivuutta Suomen olosuhteissa. MTT:n lisäksi yhteisprojektiin osallistuivat Työtehoseura r.y. ja Maatalouden laskentakeskus Oy.

Eläimiä merkitään jo nyt hyvin monella tavalla. Tärkeimpiä tapoja ovat erilaiset korvamerkit kuten EU-merkit ja erityisesti sioilla tatuoinnit. Lisäksi tunnistamiseen käytetään rekistereissä erilaisia lisätunnisteita kuten perinteistä korvamerkkitunnistetta nautakarjalla. Passiivisten elektronisten merkkien ("transponderien") numerokoodin rakenteesta on ISO-standardi olemassa jo vuodesta 1996 (ISO 11784). Standardoituja ovat myös niiden lukemiseen liityvät protokollat ja transponderien lukulaitteiden vaatimukset (ISO 11785). Koodirakenteessa on varattu 38 bittiä kansallisen tunnuksen esittämiseen ja 9 bittiä maakoodille. Bittivaraus merkitsee sitä, että käytettävissä on 274 miljardia numerovaihtoehtoa kansalliselle numerolle, minkä pitäisi riittää kaikissa maissa. On helppo arvata, että tunnuspankin hoito ja numeroiden varaukset ja jakamiset eivät tule olemaan helppo tehtävä. Siinäkin tarvitaan kansainvälistä yhteistyötä ja sopimista. Järjestelmässä tarvitaan rekistereiden sisäisiä tunnuksia, joiden avulla eläintunnusten yksiselitteisyys vasta toteutuu. Tunnusviidakkoon tarvittaisiin yksi yhdistävä tunnus, jonkalaiseksi transpondertunniste hyvin sopisi.

Transpondereita pakataan hyvin erilaisiin käyttömuotoihin (kuva 1). Tyypillisiä eläinkäytössä olevat lasikapselit asetetaan ihon alle (ns. injectable-tyyppi), erilaiset muoviset korvamerkit, kaulanauhamallit ja uudehkot keraamiset sauvat (bolukset), jotka on tarkoitettu pistettäväksi märehtijän pötsiin (tarkemminkin satakertaan). Jokaisella merkkityypillä on paljon hyviä ja paljon huonoja puolia. Kuten eläinten merkinnässä yleensäkin, merkin asentaminen, pysyminen, rikkoutumattomuus, toimiminen automaattiympäristössä ja nopea löytyminen teurastamossa ovat tärkeitä merkkityyppien kriteereitä.

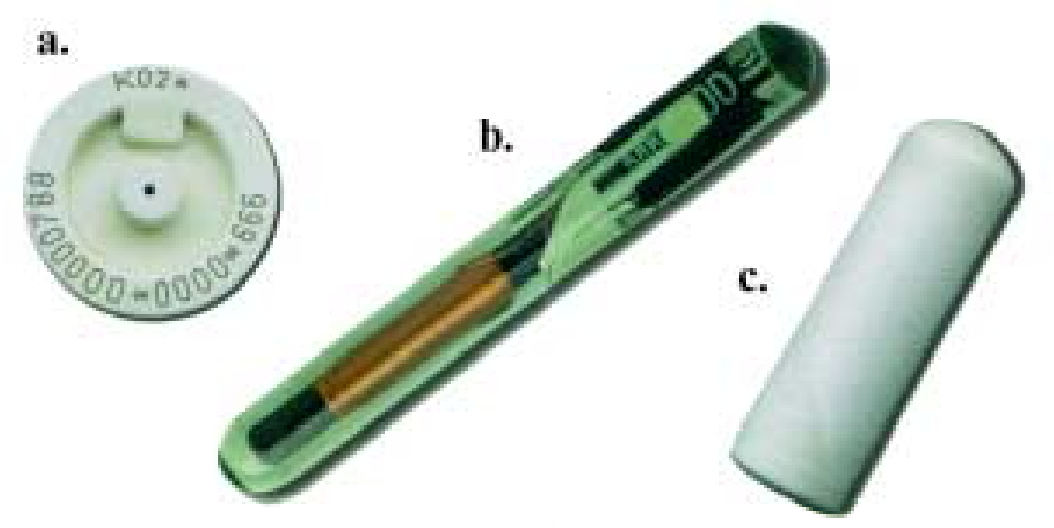

Kuva 1. Transponderityypit: a. elektroninen korvamerkki, b. ihon alle asetettava ns. injectable-tyyppi ja c. keraaminen bolus. (JRC 2001)

\section{Tavoitteet}

Tämän hankkeen ensisijaisena tavoitteena oli tutkia eläinten elektronisen tunnistusmenetelmän toimintaa ilmastossamme. Tavoitteena oli tuottaa tietoa, jonka perusteella JRC voisi asettaa realistiset kriteerit pohjoiseen tarkoitettujen laitteiden toimivuudelle. Lisäksi tavoitteena oli tuottaa tietoa koko järjestelmän/toimintaketjun toimivuudesta ja sopivuudesta Suomen olosuhteisiin. Tämä tieto antaisi 
mahdollisuuden vielä vaikuttaa tuleviin ratkaisuihin, jolloin menetelmät eivät aiheuttaisi turhia teknisiä ongelmia eikä kustannuksia merkintäketjun osallisille. Tutkimuksen tavoitteena oli myös selvittää merkintätyön helppoutta ja turvallisuutta sekä merkintäketjun kokonaisuuden toimivuutta.

\section{Aineisto ja menetelmät}

Käytännön tiloilla tehdyn toimivuustestin kohteena oli kolme erilaista karjatilaa (n. 270 eläintä). Elektronisina tunnistimina (transpondereina) käytettiin sekä elektronisia korvamerkkejä että pötsiin laitettavia keraamisia elektronisia merkkejä eli "boluksia". Eläimet tunnistettiin kädessä pidettävillä ja kiinteillä tunnistuslaitteilla. Laitteiden toimivuudesta tehtiin havaintoja. Lisäksi tutkittiin merkintä-, luenta- ja merkin talteenottotöiden sujuvuutta työntutkimusmenetelmin.

\section{Tulokset ja niiden tulkinta}

Kummankin tutkimuksessa mukana olleen transponderityypin asennus oli sangen ongelmatonta ja sujuvaa, kunhan asennustyön tekijä oli rutinoitunut. Asennusvaiheessa kirjattiin eläinten tiedot (mm. sukupuoli, rotu, syntymäaika, FI-tunnus) lukulaitteen muistiin samalla kun varmennettiin transponderin toiminta. Kun kirjaustyö tehdään tässä vaiheessa huolella, ei ole tarvetta myöhempään korjailuun. Korjaukset voidaan tehdä joko lukulaitteella itsellään (hieman rajoituksia) tai tekstinkäsittelyohjelmassa tietokoneella. Lisäksi kannattaa käyttää käsikirjanpitoa, josta selviää eläin-tunnistin -pari ongelmatilanteiden selvittämiseksi. Työstä selvittiin kahden henkilön työpanoksella: toinen asensi tunnistimet eläimiin ja toinen hoiti lukulaitteen käytön ja eläinten tietojen kirjaamisen. Aputyövoiman käyttö eläinten siirtelyyn ym. edesauttoi toki työn sujuvuutta.

Korvamerkkien asennus oli työaikamittausten perusteella selvästi sujuvampaa kuin bolusten. Työtä hidastavaksi tekijäksi muodostui tietojen kirjausnopeus lukulaitteen muistiin. Bolusten asennuksen yhteydessä oli ongelmia levottomien eläinten käsittelyssä, ja eläinten käsittelyä helpottavat lisähenkilöt olivatkin tarpeen.

Tunnistimet pitäisi lukea ennen asennusta ja heti eläimeen tapahtuvan asennuksen jälkeen. Tämä ei kuitenkaan ollut kokeiden perusteella mahdollista, koska bolukset asettuvat lopulliseen sijaintipaikkaansa verkkomahaan vasta viiden minuutin kuluttua asennuksesta. Jos eläin oli juuri syönyt juuri vähän ennen asennusta, bolus jäi pyörimään pötsiin ja sen verkkomahaan asettuminen saattoi kestää jopa puolikin tuntia. Tämän asia ei ollut tiedossa etukäteen ja aiheutti ymmärrettävästi paljon ihmetystä ja aiheettomia epäilyksiä lukulaitteen toimivuudesta

Transponderien asentaminen lypsykarjoissa oli eläinten käyttäytymisen kannalta vaivattomampaa kuin lihakarjalla. Lypsykarjoissa eläimet olivat tottuneet ihmisten läheisyyteen ja lukittaviin kytkinlaitteisiin. Erityisen hankalaa tunnistinten lukeminen käsilukulaitteilla oli parressa olevilla lihaeläimillä. Lihaeläimet eivät olleet tottuneet ihmisten liikkumiseen eläinten läheisyydessä ja ne olivat tästä syystä rauhattomia.

Transponderien toimivuudessa ei ollut moitittavaa. Käsikäyttöisten lukulaitteiden luentatavoissa oli suuriakin eroja (lukuajan pituus, antennin malli ja siten kentän muoto), joten samaa eläintä luettaessa lukupaikka hieman vaihtelee eri laitteilla. Toisaalta eri eläimillä boluksen sijaintipaikka vaihteli hieman, joten sitä joutui usein hieman hakemaan. Yleensä luenta-ajat jäivät alle 10 sekuntiin, jota voidaan pitää tyydyttävänä. Korvamerkkien luenta oli huomattavasti helpompaa ja ennen kaikkea turvallisempaa.

Käsikäyttöisten lukulaitteiden ergonomia ja käyttömukavuus olivat varsin vaatimatonta luokkaa. Laitteiden muotoilu oli puutteellinen ja lukulaitteessa käytettävät antennit liian lyhyitä jonka takia lukuvaiheessa oli mentävä lähestulkoon eläimen alle, joka on jo selvä työturvallisuusriski.. Lyhyttä antennia käytettäessä joudutaan menemään lähelle eläintä, mikä lisää tapaturmariskiä. Laitteiden ulkokuoren materiaali oli yleensä metallia tai muuta hyvin kylmää johtavaa materiaalia, joka vaikutti laitteen käsiteltävyyteen talvella. Käsilukulaitteissa ei ollut kantohihnoja tai -remmejä, jolloin lukulaite saattaa helposti pudota lantakuiluun, rikkoutua tai joutua eläinten tallottavaksi. Käsilukulaitteiden käytössä tunnistuksen yhteydessä tulisi kuulua kunnollinen ääni- ja valomerkki. Käytössä olleiden käsilukulaitteiden ääni ja valomerkit olivat hyvin huomaamattomia. Tuotantorakennuksessa on harvoin täysin hiljaista. Yleensä eläimet, rehunjakolaitteet ja ilmastointikoneet aiheuttavat voimakastakin meteliä, jolloin heikot merkit eivät kuulu. Eläimet hermostuvat helposti näistä vieraista laitteista ja yrittävät potkia joko itse laitetta tai sen käyttäjää.

Staattisissa lukulaitteissa esiintyi positiivisia alkukokemuksia lukuun ottamatta yllättävän paljon ongelmia. Kolmesta laitteesta vain yksi toimi koko testin ajan edes suunnilleen toivotulla tavalla. Yh- 
teen laitteista ei saatu lainkaan toimivaa yhteyttä tietokoneella, joten se lähetettiin takaisin Italiaan. Toisessakin oli hieman ongelmia yhteyden muodostamiseen tarkoitetussa ohjelmistossa ja siihen saatiinkin yhteys ainoastaan yleisterminaaliohjelmalla. Kolmas toimi yleensä näiltä osin, mutta senkin kanssa oli ongelmia antennin kentän kanssa. Ensiksi epäiltiin, että ongelma olisi ollut paikkakohtainen eli lähettyvillä olisi jokin häiriölähde, koska lukulaite sattui häiriintymään aina samassa paikassa. Lopulta kuitenkin kävi ilmi, että pienikin muutos antennin sijaintipaikassa saattoi aiheuttaa merkittäviä eroja kentän voimakkuudessa. Suitian tutkimustilalla kenttää häiritsi perinteinen lypsyasema, jonka sisääntuloportilla olevat antennit vaikuttivat haitallisesti tunnistussysteemiin, joka oli noin 7 metrin päässä. Jos vain kenttä saatiin normaaliksi (lukuetäisyys $\mathrm{n} .70-100 \mathrm{~cm}$ ), niin dynaaminen luenta oli sangen sujuvaa. Tämä edellytti, että eläinten kierrätys luentapaikalle toimi hyvin.

\section{Johtopäätökset}

Tutkimuksessa mukana olleiden merkintälaitteistojen vakavimmat toimivuusongelmat näyttivät liittyvän pääasiassa muihin tekijöihin kuin suoranaisesti kylmään käyttöympäristöön. Korvamerkityistä eläimistä suurin osa asusti talven yli metsässä, mutta yksikään merkki ei vahingoittunut talven aikana. Toisaalta lukulaitteiden akut tuntuivat kestävän pakkasta sangen hyvin ja ainoastaan käsikäyttöisten lukulaitteiden nestekidenäyttöjen hienoinen himmeneminen seurasi jopa hieman normaalia kovempaa käyttöä, jossa laitteita makuutettiin pakkasessa parikin tuntia testien välillä. Staattisissa lukulaitteissa ei ollut verkkovirtaa käytettäessä mitään ongelmia. Akkukäyttö ja tietokoneen näyttö saattoivat aiheuttaa ongelmia. Yhteenvetona voidaankin todeta, että järkevä talvikäyttö laitteita tarpeettomalta kylmyydeltä varjellen ei aiheuta lisäongelmia (jos laitteet ovat selvinneet JRC:n nykyisistä laboratoriotesteistä). Antennien lukuetäisyydet näyttävät olevan kriittinen toimivuustekijä. Sähkömagneettisten häiriöiden esiintymisestä saatiin selviä viitteitä staattisilla lukulaitteilla. Huono käytettävyys nousi tärkeimmäksi käyttöä vaikeuttavaksi tekijäksi. Merkintälaitteistojen ergonomiseen tasoon pitäisikin kiinnittää pikaisesti huomiota sekä peruskäytön että erityisesti kylmätyön kannalta.

Rakennussuunnittelussa pitäisi jo nyt ottaa ennakkoa elektronisen merkinnän tulemiselle. Tarvitaan uudenlaista rakennusten logistisen käytön suunnittelua. Tarvitaan sellaisia tunnistuskäytäviä, erottelupaikkoja, punnituspaikkoja ja eläinten käsittelypaikkoja, joita ei ole Suomen oloissa eläinrakennuksiin tai sen lähelle totuttu suunnittelemaan. Elektronisten tunnistimien asentamista ja toimivuuden tarkastamista varten kotieläinrakennuksessa tulisi olla kiinteä asennuspaikka, jossa on lukittavat kytkinlaitteet. Lypsykarjatiloilla edellä mainittu vaatimus tulee täytetyksi lähes aina, mutta varsinkin lihakarjakasvattamoissa ei useinkaan ole lukittavia parsi- tai sairaspaikkoja. Tilapäisen aitaukset ja parsirakennelmat vaarantavat työntekijöiden työturvallisuutta. Edellä mainitut vaatimukset ovat tärkeitä erityisesti siirryttäessä käyttämään elektronisia tunnistimia nykyisten eläintunnistinten sijaan, jolloin asennus- ja tunnistustyötä joudutaan tekemään täysikasvuisilla eläimillä. Myöhemmin, asennettaessa tunnistimia nuorille eläimille, työturvallisuusriski on vähäisempi. Teurastamoidenkin tulisi valmistautua merkkien käsittelyyn.

Samaa tunnistinta olisi rationalista käyttää kaikissa mahdollisissa tunnistustöissä. Antennityypeissä ja niiden sijoittelussa tulee väkisinkin ongelmia, jos eläin pitäisi pystyä tunnistamaan korvamerkistä korkealta tai keraamisesta boluksesta mahan alta tai sivusta. Uusasennuksissa mahdolliset ongelmat pystytään paremmin hoitamaan, mutta tunnistamisen pitäisi onnistua myös olemassa olevien lypsyasemissa tai ruokintakioskeissa.

Huomattavaa lisäarvoa elektronisesta tunnistamisesta saadaan vasta silloin, kun tunnukseen liitetään hyödyllistä tai pakollista tietoa. Täyden hyödyn toteutuminen vaatii hyvää valtakunnallista järjestelmää, tietopankkia ja rekisteriä, josta kaikki eri osapuolet voivat saada toimintaansa tukevaa tietoa. Eläinten elektroniseen merkintään pitäisi lähteä laajalla teknisellä ja hallinnollisella rintamalla niin, että sen kaikki edut saataisiin heti käyttöön. Mikään ei estä toiminnan kehittämistä itsenäisillä pilottisektoreilla, mutta silloinkin pitäisi olla olemassa järkevä kokonaissuunnitelma ja sopimukset noudatettavista standardeista ja ennenkaikkea lopullisista raameista, joihin yhteinen toimintamalli aikanaan asettuu. Suomeen tarvittaisiinkin pikaisesti kattava koordinointielin, joka ottaisi tehtäväkseen elektronisen merkinnän kehittämisen ja pyrkisi niveltämään sen mahdollisen saumattomasti olemassa oleviin merkintäjärjestelmiin ja rekistereihin.

\section{Kirjallisuus}

Haapala, H. 2001. Eläinten elektroninen tunnistus - apuväline tulevaisuuteen. Lihatalous 6. 
SUOMEN MAATALOUSTIETEELLISEN SEURAN TIEDOTE NRO 18

JRC 2001. Monitoring of Livestock (IDEA). CODE ISIS-11. Saatavilla elektronisessa muodossa: http://webfarm.jrc.cec.eu.int/scripts/db/bld/builder.asp?PRJ=PGM\&VKEY=220\&SEC=DETAIL 